Revista Bioética

Print version ISSN 1983-8042 On-line version ISSN 1983-8034

Rev. Bioét. vol.28 no.2 Brasília Abr./Jun. 2020

Doi: 10.1590/1983-80422020282396

\title{
PESQUISA
}

\section{Attitudes of doctors and medical students toward patients with suicidal ideation}

Gabriela do Prado Rocha ${ }^{1}$, Gerardo Maria de Araújo Filho ${ }^{1}$, Lazslo Antônio Ávila ${ }^{1}$

1. Departamento de Psiquiatria e Psicologia Médica, Faculdade de Medicina de São José do Rio Preto (Famerp), São José do Rio Preto/SP, Brasil.

\begin{abstract}
Considering suicide is a public health problem, this study identified misconceptions about patients at risk of suicide as well as strategies to manage patients and their families, also verifying changes in conceptions and attitudes throughout graduation. We applied a questionnaire with five categories: "medical confidentiality," "deontology," "medical negligence," "graduation," and "myths and conceptions". One hundred and twenty-six subjects participated in the research: 45 (35.7\%) first-year medical students, 48 (38.1\%) interns, and 33 (26.2\%) doctors. The variables were analyzed, and the difference between groups was significant for 15 questions (62.5\%). In one question (myths and conceptions) the answers were distant from the expected, and in two questions (myths and conceptions, deontology) the result did not give adequate information. We observed improvements at medical graduation for most of the studied aspects; among the deficiencies, we highlight those related to compulsory notification, electroconvulsive therapy, and the responsibility of doctors.
\end{abstract}

Keywords: Suicide. Ethics. Malpractice. Education-Medicine.

\section{Resumo}

\section{Atitudes de médicos e estudantes de medicina com pacientes com ideação suicida}

Partindo do princípio de que o suicídio é problema de saúde pública, este estudo identificou concepções equivocadas sobre o assunto, estratégias de manejo dos pacientes e familiares, e verificou se há mudanças nessas concepções e atitudes ao longo da graduação. Foi elaborado questionário com cinco categorias: "confidencialidade médica", "deontologia", "negligência médica", "graduação", e "mitos e conceitos". Cento e vinte e seis sujeitos participaram da pesquisa: $45(35,7 \%)$ alunos do primeiro ano de medicina, $48(38,1 \%)$ estagiários e $33(26,2 \%)$ doutores. As variáveis foram analisadas, e a diferença entre os grupos foi significativa para 15 questões (62,5\%). Em uma questão (mitos e conceitos) houve distanciamento da resposta esperada e em duas questões (mitos e conceitos, deontologia), o resultado não deu a informação adequada. Verificamos melhoras durante a graduação para a maioria dos aspectos considerados; dentre as deficiências, destacaram-se as relacionadas à notificação compulsória, eletroconvulsoterapia e responsabilização do profissional médico. Palavras-chave: Suicídio. Ética. Imperícia. Educação-Medicina.

\section{Resumen}

Las actitudes de médicos y estudiantes de medicina sobre los pacientes con ideación suicida

Considerando el suicidio como un problema de salud pública, este estudio identificó las concepciones erróneas sobre el tema, las estrategias para atender a los pacientes y sus familias y verificó los cambios en los conceptos y actitudes de estudiantes de medicina durante la graduación. Se elaboró un cuestionario con cinco categorías: "confidencialidad médica", "deontología", "mala praxis médica", "graduación", y "mitos y conceptos". De los 126 participantes $45(35,7 \%)$ eran estudiantes del primer año de medicina, $48(38,1 \%)$ becarios, y $33(26,2 \%)$ médicos. Las variables se analizaron estadísticamente, y la diferencia entre grupos fue significativa para 15 preguntas (62,5\%). Una pregunta (mitos y conceptos) tuvo una respuesta inesperada, y dos preguntas (mitos y conceptos, deontología) no presentaron un resultado adecuado. Se observaron mejoras durante la graduación en la mayoría de los aspectos estudiados; entre las deficiencias, se destacaron la notificación obligatoria, la terapia electroconvulsiva y la responsabilidad del profesional médico.

Palabras clave: Suicidio. Ética. Mala praxis. Educación-Medicina.

Approval CEP-Famerp CAAE 44655715.3.0000.5415

The authors declare no conflict of interest. 
Suicide is defined by the World Health Organization (WHO) ${ }^{1}$ as the intentional taking of one's own life; it is deadlier than some natural catastrophes and wars $^{2}$. In 2012, suicide was ranked second in the list of the main factors related to death between 15 and 29 years of age $^{3}$, after traffic accidents ${ }^{4}$. According to the Global Health Observatory Data Repository ${ }^{5}$, in the same year, six deaths by suicide were recorded in Brazil for every 100 thousand inhabitants. Among women, this rate is $2.5 / 100$ thousand and among men, 9.4/100 thousand.

Despite this, the statistics related to suicide do not compute the outcomes related to selfdestructive actions ${ }^{2}$. Worldwide, suicide is among the three most important causes of death in the economically most productive group (1544 years) ${ }^{6}$, and in addition to causing economic loss, it entails important social and psychological penalties ${ }^{7}$. Regarding economic analysis, there are relevant expenses related to social protection and health care systems resulting from suicides and suicide attempts ${ }^{8}$.

Suicide is considered a public health problem and must be approached by social programs ${ }^{9}$ since the deaths are largely preventable. Moreover, the government's obligation to provide resources for the prevention of suicide is indisputable ${ }^{6}$. A significant hurdle that plagues the field of prevention is related to uncovering how best to identify people at risk for suicidal behavior as mental health treatment is not always sought ${ }^{10}$. In addition, the difficulties faced by health professionals to treat these subjects need to be identified, as there is evidence that signs of suicidal behavior in young people go unnoticed and are not treated by general practitioners ${ }^{11}$.

The most common type of contact occurs in outpatient clinics, reinforcing the importance of designing and integrating suicide prevention strategies into routine clinical care and not only in high-risk or acute care settings ${ }^{12}$. An American study found that more than $38 \%$ of those who attempted suicide sought medical care within one week prior to the attempt and $95 \%$ within the previous year, usually in primary care and general medical outpatient clinics ${ }^{13}$. Risk factors such as depression are not systematically identified and managed by general practitioners, and self-mutilation in young people is often underestimated ${ }^{3}$. We then must consider the important role of general practitioners in the investigation of mental health problems ${ }^{14}$ and suicide prevention.
Suicide attempts are 10 to 20 times more frequent than deaths from suicide ${ }^{15}$ among patients in emergency departments for attempted selfextermination. Furthermore, it is estimated that 30 to $60 \%$ of those cases had previous suicide attempts, as well as 10 to $25 \%$ of them would incur in future attempts in the subsequent 1-year period ${ }^{16}$. "Prior suicide attempts" is the single most important risk factor related to suicide ${ }^{10}$. The number of attempts is related to the increase of the risk and the reduction of the period between attempts ${ }^{16}$, hence the importance of identifying and treating this patient adequately. A study showed that the first year after the onset of ideation symptoms is the most critical period, since in $60 \%$ of cases there is progression from ideation to planning and then to attempt ${ }^{17}$, showing that, for medical interventions to be successful, they must be implemented quickly.

Faced with challenges that permeate suicide prevention in today's public health scenario, the medical curriculum should incorporate better guidance on identifying and meeting mental health needs ${ }^{14}$, since the adequate reception of the person for hospital care after an attempted suicide is essential to establish compliance with treatment ${ }^{16}$.

The improvement of the reception after an attempted suicide should always consider the Brazilian Code of Medical Ethics ${ }^{18}$, guided by the four ethical principles of Beauchamp and Childress ${ }^{19}$-autonomy, non-maleficence, beneficence and justice-, in order to avoid false interpretations regarding the patient's autonomy, consent and confidentiality.

Patient autonomy and consent are controversial issues when it comes to suicidal patients ${ }^{20}$. Physicians are obliged to intervene in lifethreatening acts and may break secrecy in situations of death or suicide ${ }^{2}$. In these cases, beneficence and non-maleficence are more important than considerations about patients' ability to make decisions, i.e., their autonomy, justifying treatment or even compulsory hospitalization ${ }^{21}$.

Compulsory admission is justified as a way of preventing suffering and providing appropriate treatment, or protecting the patient from harm to himself or others ${ }^{22}$. In general, in these cases, autonomy is a value to be promoted or restored, not the right to have the individual's wishes respected ${ }^{21}$. The doctor is faced with a conflict between what he believes to be right and what is his legal responsibility ${ }^{21}$, and when this conflict is badly solved, there is litigation based on the premise 
that most suicides can be prevented if appropriate attitudes are taken ${ }^{20}$.

This situation is well portrayed by Welsh and Deahl's description of modern psychiatry, quoted by Feiring and Ugstad as uncomfortably wedged between the territories of law and medicine, between coercion and care ${ }^{23}$. There is a lack of capacity for these patients to be fully cared for and for referrals to sectors with resources to treat their problems ${ }^{24}$, and some systematic reviews indicate that medical education regarding the recognition and treatment of depression may reduce suicide rates ${ }^{11}$. A study in the United States showed that there is relation between training and the ability to treat suicidal patients; professionals who feel able to treat such patients can better understand them and, consequently, treat these cases better ${ }^{25}$. Some studies have reported a drop in suicide rates following the implementation of continuing education on depression for general practitioners ${ }^{26}$. Another study protocol works with the hypothesis that patients treated by multiprofessional teams who received adequate training will recover faster from suicidal ideation, which may decrease suicide attempts ${ }^{27}$.

Research and knowledge about suicide prevention has been growing, but despite this, taboo and stigma persist and people often do not look for help or are abandoned ${ }^{7}$. The stigma attached to mental illness, the certainty that the situation is irreversible, and the criminalization of suicide in some countries favor the resistance to look for help for emotional distress ${ }^{9}$.

According to Kovács ${ }^{2}$, data from the Brazilian Ministry of Health show that $40 \%$ of the people who committed suicide were in health centers in search of relief, but, paradoxically, they found judgment, blame and lack of protection, which increased their suffering and feeling of abandonment. Suicidal behavior and self-harm have key mechanisms like affliction, impulsivity, emotional suffering and despair, and this can easily be falsely interpreted as a behavior to draw attention, and consequently be treated negatively and without compassion, affecting the involvement and therapeutic management ${ }^{3}$. However, in societies where there has been a reduction in prejudices and misjudgments, the search for aid has increased ${ }^{8}$.

Awareness and understanding of mental health by the general population should include government-and other institutions'-efforts to address the stigma of suicide ${ }^{6}$. Public health suffers serious consequences stemming from the negative influence that this stigma has on the quality of communication and the recording of data related to suicidal behavior ${ }^{6}$.

In this paper, we sought to identify the conceptions and possible attitudes of medical scholars and physicians regarding patients with suicidal ideation or those who attempted suicide, to verify their understanding of the law and the Code of Medical Ethics in force in Brazil, and to verify if these conceptions and possible attitudes change during graduation. This research also aims to promote among the interviewees the book Suicide: Inform to prevent ${ }^{28}$, prepared by the Federal Council of Medicine (CFM) in partnership with the Brazilian Association of Psychiatry (ABP).

\section{Method}

This survey regarded the possible attitudes and conceptions of doctors and medical students in respect to suicidal patients. This is a cross-sectional study using quantitative and qualitative methods carried out at the School of Medicine of São José do Rio Preto (Famerp), São Paulo, Brazil, and the tertiary Hospital de Base of Famerp, a regional and national reference center for care and education.

As an instrument of analysis and based on the directive published by the $A B P^{28}$, the researchers elaborated a questionnaire (Appendix) to collect sociodemographic data, and included a survey with affirmations with yes/no responses or a five-point Likert scale ("I strongly disagree", "I disagree", "I do not know", "I agree", "I strongly agree").

The data that emerged from the questionnaire were grouped in five categories: medical confidentiality; deontology; medical negligence; graduation; and myths and conceptions. Data were collected between August 2015 and July 2016. The qualitative variables were analyzed by the ShapiroWilk test (normality) and Kruskal-Wallis test in the BioEstat 5.0 program. P-values $<0.05$ were considered statistically significant.

A total of 126 individuals were studied: a group of 45 first-year students (FG), a group of 48 interns (IG), and a group of 33 doctors (DG). The inclusion criteria aimed at establishing a sample that represented the different phases of the medical training in order to verify if the aspects investigated in the protocol changed during that period. Participants were recruited through convenience sampling based on accessibility, interest in the study, 
and willingness to participate. All participants were informed of the characteristics of the study and they confirmed their willingness to participate by signing an informed consent form. Subsequently they completed the questionnaire to record data.

\section{Results}

Of the 93 students included in the study, $45(48.4 \%)$ were in the first year of the medical course and 48 (51.6\%) were interns, of whom 27 (56.3\%) were in the fifth year and 21 (43.7\%) in the sixth year. Of the DG, comprised of 33 doctors, eight (24.2\%) were preceptors and 25 (75.8\%) were residents. Data on the workplace of the DG and frequencies of care for patients with suicidal ideation or attempted suicide are shown in Table 1 . The data collected were divided in five categories (Chart 1 ) with the objective of gaining a better understanding of the topic addressed.

Three questions (Chart 1 ) investigated aspects related to medical confidentiality. There were significant differences $(p<0.05)$ for questions 11 and 22 between FG and IG, and between FG and DG (Table 2). No statistically significant difference was found between the groups for question 18; however, as predicted, the majority of the participants chose the answer "I agree" or "I strongly agree": 35 (77.8\%) of FG, 35 (72.9\%) of IG, and 26 (78,8\%) of DG.

Medical deontology was assessed in five questions of the research protocol (Chart 1) with significant differences being observed between the groups for questions 19, 21, and 23, which deal with urgency/emergency management, compulsory notification of suicide attempts and compulsory hospitalization, respectively. Regarding urgency/ emergency management, there was a statistically significant difference between FG (mean=3.64) and DG (mean=4.21). In the question about compulsory notification, the difference between FG (mean=3.15) and DG (mean=3.63) was significant, and 36 students (80\%) in the FG answered "I do not know," while in the DG, 19 physicians (57.6\%) choose the "I agree" or "I strongly agree" answer. Concerning compulsory hospitalization, significant differences were found between FG (mean=3.07) and IG (mean=3.73), and between FG and DG (mean=3.94).

There was no increase of agreement in relation to a higher graduation for question 12 . Among thosewho answered "I agree" or "I strongly agree" on that question, 32 (71.1\%) belonged to FG, $26(54.1 \%)$ to IG and $21(63.7 \%)$ to DG. Regarding question 24, although the result was not significant, the results were close to the "expected response," according to higher graduations.

Aspects related to medical malpractice were analyzed by four questions; questions number 1 and 10 , related to the patient's autonomy, had $p<0.05$ when FG (mean=3.09 and mean=2.51, respectively) and DG (mean=2.36 and mean=2, respectively) were compared. The expected answer for both was "I strongly disagree". The findings suggest that these aspects had probably been taught in the medical graduation course. The results of the three groups for question 5 are close to what was expected ("I strongly disagree"). However, the answers obtained for question 13 (mean=2.93) do not correspond to the expected.

Table 1. Characterization of the Medical Group (DG)

\begin{tabular}{|c|c|c|}
\hline Characteristics & $\mathbf{n}$ & $\%$ \\
\hline \multicolumn{3}{|l|}{ Gender } \\
\hline Male & 19 & 57.6 \\
\hline Female & 14 & 42.4 \\
\hline \multicolumn{3}{|l|}{ Workplace } \\
\hline Urgency/Emergency & 7 & 21.2 \\
\hline Intensive care unit & 2 & 6.1 \\
\hline Oncology & 9 & 27.3 \\
\hline Medical clinic infirmary & 11 & 33.3 \\
\hline General surgery infirmary & 1 & 3.0 \\
\hline Psychiatry & 15 & 45.5 \\
\hline \multicolumn{3}{|l|}{ Occupational situation } \\
\hline Preceptor & 8 & 24.2 \\
\hline \multicolumn{3}{|l|}{ Resident } \\
\hline First year & 8 & 24.2 \\
\hline Second year & 11 & 33.3 \\
\hline Third year & 5 & 15.2 \\
\hline Fourth year & 1 & 3.0 \\
\hline \multicolumn{3}{|c|}{ Patient with suicidal ideation / week } \\
\hline None & 2 & 6.1 \\
\hline 1 to 5 & 25 & 75.8 \\
\hline 6 to 10 & 6 & 18.2 \\
\hline 11 to 15 & 1 & 3.0 \\
\hline \multicolumn{3}{|c|}{ Patient with suicide attempt / week } \\
\hline None & 3 & 9.1 \\
\hline 1 to 5 & 29 & 87.9 \\
\hline 6 to 10 & 1 & 3.0 \\
\hline
\end{tabular}


Chart 1. Categories of issues addressed in the research protocol

\begin{tabular}{l} 
Questions \\
\hline Medical confidentiality
\end{tabular}

11. The breach of medical secrecy in situations involving suicide can be considered ethical and legal.

18. When identifying a patient at medium risk of committing suicide, the proper conduct would be to request permission to contact family, friends and/or colleagues and explain the situation without alarm or understate, giving only the necessary information and preserving the confidentiality of other information on the particularities of the individual.

22. According to the Brazilian Code of Medical Ethics, the doctor shall keep confidential information that he knows about in the performance of his duties. Medical confidentiality must be respected even in situations in which the patient has suicidal ideation and is at risk of committing suicide.

Deontology

12. The risk assessment for suicide should be made for all patients, regardless of the presence of explicit suicidal complaints.

19. Urgency/emergency: 24-hour surveillance should be structured by someone from the health care team or caregiver, if evaluated as qualified, until medical reassessment. Objects that can be used to injure oneself or others (knives, sharp instruments, medicines, belts and ropes) should be removed from the patient's access, and their belongings should be searched for these items. Doors, including the bathroom, should not be locked.

21. Since June 2014, the National List of Compulsory Notification of diseases, injuries and public health events in public and private health services, throughout the national territory, includes attempted suicide as an immediate compulsory notification within 24 hours from the knowledge of the occurrence.

23. In cases of high risk of suicide, the doctor may hospitalize the patient against his will in order to ensure his life.

24. It must be ensured that the person who has just made a suicide attempt is immediately put on treatment to reduce the risk of re-attempting and completing suicide.

Medical negligence

1. Suicide is an individual decision, since one has the full right to exercise free will.

5. When an individual shows signs of improvement or survives a suicide attempt, they are out of danger.

10. Patients who are severely depressed, but cognitively intact, may be considered competent to refuse antidepressant medication.

13. Failure to examine the patient's propensity to commit suicide or to implement an appropriate precautionary plan after the potential for suicide is predicted may lead to professional liability for injury to the individual in a suicide attempt.

Graduation

26. Were you trained during your graduation to treat patients with suicidal ideation?

27. Do you feel prepared to attend patients with suicidal behavior (thoughts, attempts, planning)?

Myths and conceptions

2. When a person thinks about committing suicide, they will risk suicide for the rest of their life.

3. People who threaten to kill themselves will not do so, they just want to get attention.

4. If a person felt depressed and was thinking about committing suicide, and in the next moment feels better, it usually means that the problem is over.

6. We should not talk about suicide as this can increase the risk.

7. Effective treatment of mental illness is the most important pillar of suicide prevention. After the treatment of mental illness, the desire to kill oneself disappears.

8. Most suicidal people speak or show signs about their ideas of death.

9. Talking to someone about it can ease the anguish and tension that suicidal thoughts bring.

14. Every patient who talks about suicide has potential risk and deserves special investigation and attention.

15. The verbal approach can be as or more important than medication.

16. Although most people at risk of suicide have some mental disorder, most do not seek a mental health professional.

17. Electroconvulsive therapy is still the most effective treatment for depression, being reserved primarily for selected cases such as severe depressions, refractory depressions, depressions with psychotic symptoms and depressions with high risk of suicide.

20. Suicide prevention should start only in centers with a focus on mental health. 


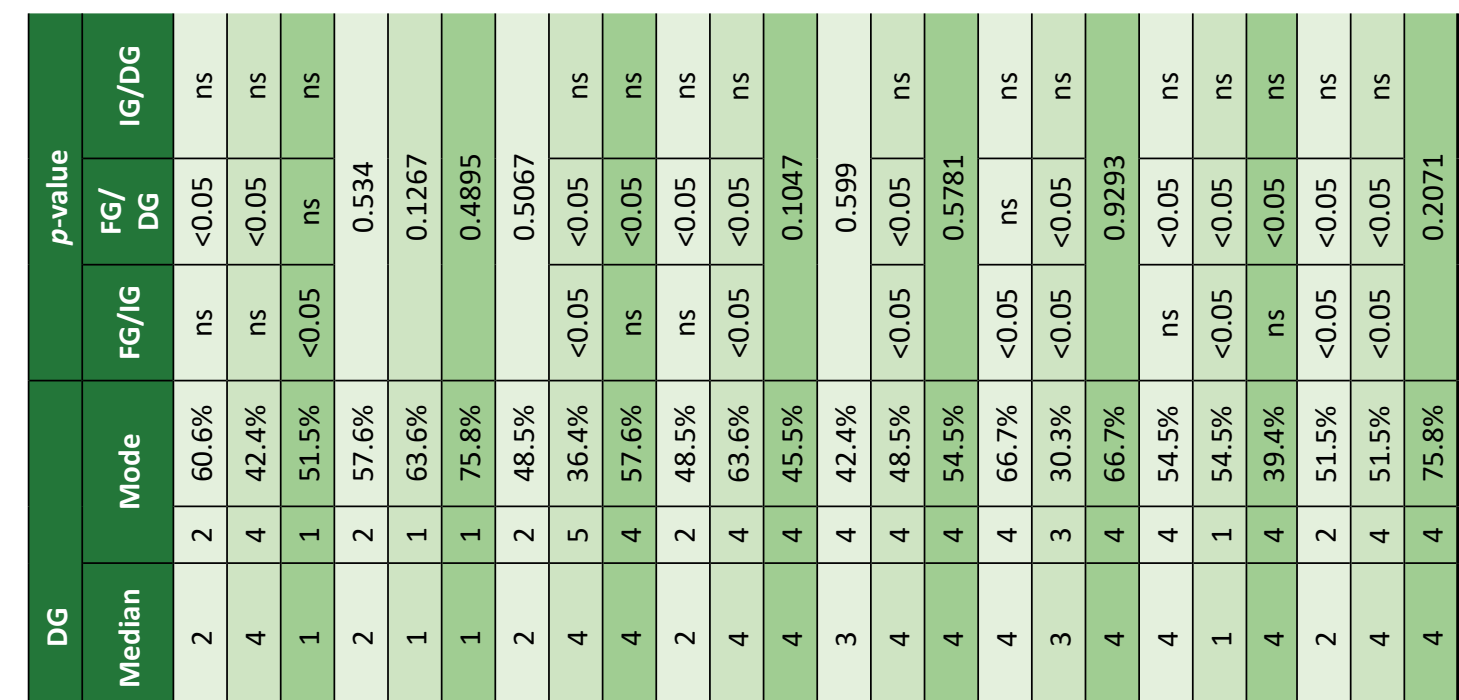

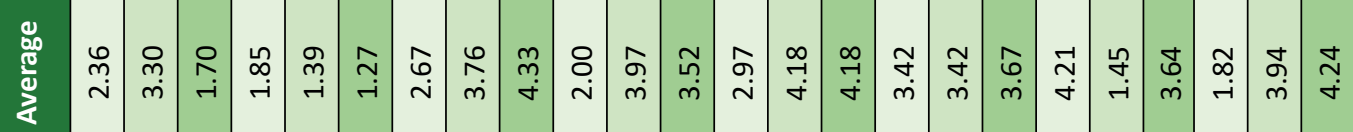

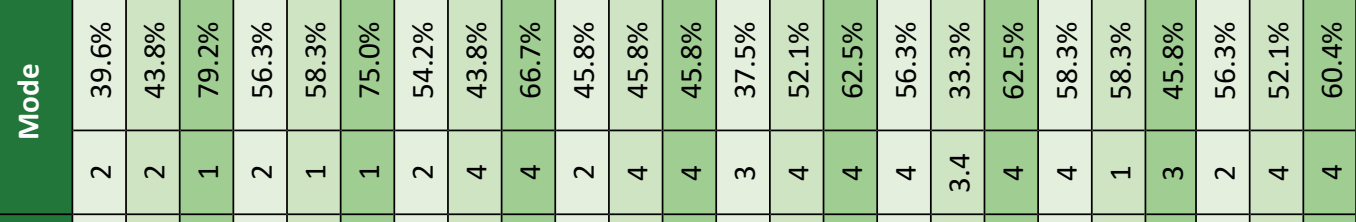

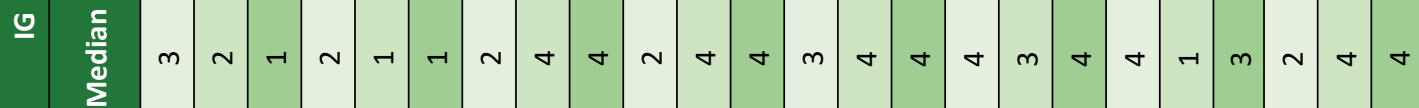

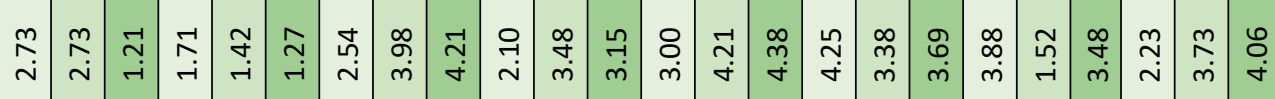

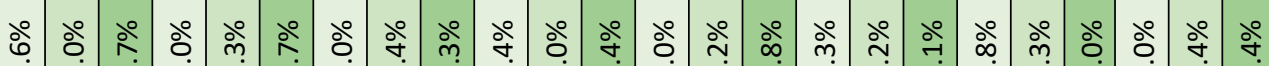
¿

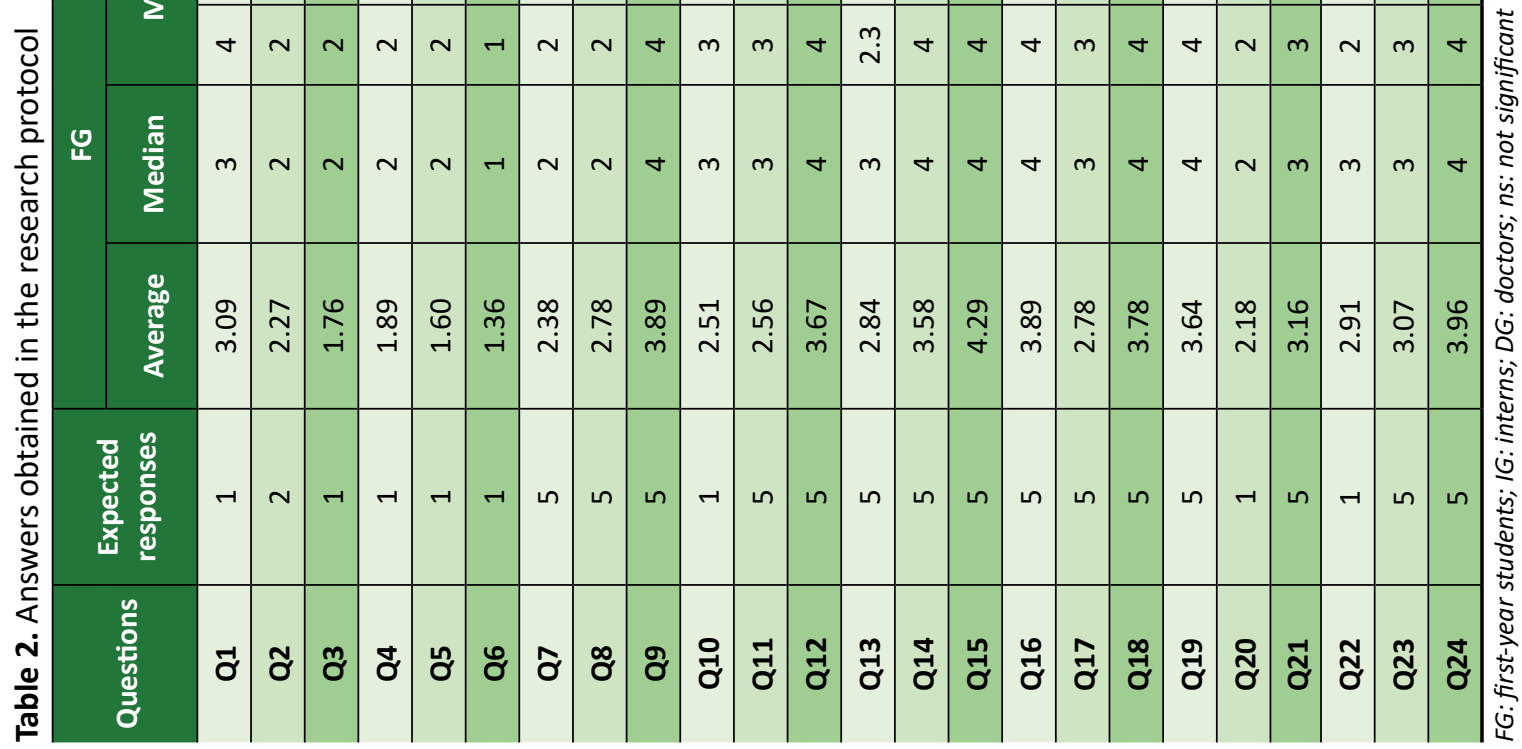


Two questions of the protocol investigated aspects of graduation. When inquired about being prepared during the graduation to treat patients with suicidal ideation, 12 (25.5\%) interns answered "I agree" and none answered "I strongly agree" whereas 12 (36.4\%) of the DG answered "I agree" or "I strongly agree" $(p=0.31)$. In relation to being prepared to treat patients with suicidal behavior, 37 interns (77.1\%) did not feel prepared; among physicians, 13 (39.4\%) answered that they were not prepared $(p=0.021)$.

Out of the statements in the research protocol, 12 investigated aspects related to myths and conceptions. There was a significant difference between groups for eight questions $(2,3,8,9,14,16$, $17,20)$. Regarding question 2 , there was a distance between the answer given by the participants and the expected response during graduation as indicated by the means found in the study groups (FG mean=2.26; IG mean=2.72; and DG mean=3.30), with the difference being significant between FG and DG $(p<0.05)$.

In the other questions with $p<0.05$ there was an approximation to the expected response during graduation. Regarding questions in which there was no significant difference between the three groups analyzed $(4,6,7,15)$, only question 7 shows different results from what was expected ("I agree" and "I strongly agree"; FG: mean=2.37; IG: mean=2.54; and DG mean=2.66).

\section{Discussion}

According to the Brazilian Code of Medical Ethics ${ }^{18}$, doctors must keep information they gain while performing their duties confidential, but in the case of imminent risk of death ${ }^{2,18}$ the physician must communicate the fact to family members, that is, break the secrecy in order to preserve the patient's life. According to Preventing suicide: a manual for primary care professionals ${ }^{29}$, prepared by the Brazilian Ministry of Health with the Pan American Health Organization and State University of Campinas, even without the consent, in the face of a risk situation that justifies the breach of confidentiality, someone sympathetic to the patient must be located. In this study, the means of the results obtained became closer to the expected as the participant's education increased and were similar to the results found in the literature, indicating that this knowledge is learned during medical graduation.
Regarding medical deontology in relation to suicidal behavior, the main responsibilities of the health professional pertains to the ability to identify, minimize and treat risk factors, always aiming at patient protection ${ }^{30}$. The participants of the current research appear to be well instructed in urgency/ emergency management and the possibility of involuntary hospitalization. Misinformation was found regarding compulsory notification: some doctors were unaware of the Ordinance 1,271/2014 of the Brazilian Ministry of Health ${ }^{31}$, which defines the National List of Compulsory Notification of diseases, injuries and public health events in public and private health services throughout Brazil. Accordingly, attempts to commit suicide must be notified within 24 hours from the event ${ }^{31}$.

Another issue found in undergraduate studies is the assessment of the risk of suicide; since there is no way to predict who will commit suicide, the individual risk presented by each patient should be evaluated $^{30}$. Bertolote, Mello-Santos, and Botega ${ }^{30}$ reinforce the importance of investigating suicidal ideation and risk factors in all patients hospitalized in clinical emergencies and on non-psychiatric wards.

Regarding the ethics of principles, the suicidal behavior emerges as an important circumstance in which the primordial principle of patient's autonomy can be superseded by the principles of beneficence and non-maleficence, since neglecting the risk to life and mental suffering resulting from suicidal behavior can incur in ethical misconduct. About this issue, the Brazilian Code of Medical Ethics states that the physician is prohibited [from] causing harm to the patient, by action or omission, characterized as malpractice, recklessness or negligence and that medical liability is always personal and cannot be presumed ${ }^{32}$. The results in this study indicate that the participants do not see the professional as responsible in cases of injuries resulting from attempted suicide after failure of the medical examination or the implementation of precautions after the potential for suicide is predicted.

Training to deal with patients with ideation, thoughts and suicide attempts improves overall medical skills; but participants reported that they were not adequately prepared during graduation. According to the directive developed by CFM in partnership with $\mathrm{ABP}$, effective treatment of mental illness is the most important pillar of suicide prevention. After treatment (...) the desire to kill oneself disappears ${ }^{33}$. Such a concept does not appear to be well established among our study 
group, who believes that once the individual has thought of killing oneself, the risk of suicide will be a lifelong condition.

\section{Final considerations}

This research has some limitations that can be minimized in future studies. One is that it was performed with physicians and medical students from a specific region of Brazil, that is, the results obtained cannot be generalized. Another limitation, despite all the care, concerns the possible biases of information on the part of the interviewees, such as lack of attention or understanding, haste to respond and self-censorship.
However, these limitations do not devalue the results of the study and the conclusions reached. This paper records the opinion and knowledge of physicians and medical students linked to the School of Medicine of São José do Rio Preto, São Paulo, Brazil, and its results may be useful for future comparisons, since this type of study should try to cover a greater number of institutions, and more medical doctors and academics.

In this sense, we suggest the adoption of continuous education measures with a more focused approach on this theme. Suicides are complex phenomena that involve various disciplines, and in the words of Kovács, in this context, simplistic responses should give rise to reflection and multidisciplinary debate ${ }^{34}$.

This research was supported by the Institutional Program for Scientific Initiation Scholarships (Pibic) from Famerp.

\section{References}

1. World Health Organization. mhGAP intervention guide for mental, neurological and substance use disorders in non-specialized health settings [Internet]. Genebra: WHO; 2010 [acesso 18 set 2018]. Disponível: https://bit.ly/39mKC8p

2. Kovács MJ. Revisão crítica sobre conflitos éticos envolvidos na situação de suicídio. Psicol Teor Prát [Internet]. 2013 [acesso 9 jul 2016];15(3):69-82. Disponível: https://bit.ly/2WHWmjb

3. Michail M, Tait L. Exploring general practitioners' views and experiences on suicide risk assessment and management of young people in primary care: a qualitative study in the UK. BMJ Open [Internet]. 2016 [acesso 11 jul 2016];6:e009654. Disponível: https://bit.ly/33LOHnf

4. World Health Organization. World health statistics 2016: monitoring health for the SDGs: sustainable development goals [Internet]. Genebra: WHO; 2016 [acesso 6 ago 2016]. Disponível: https://bit.ly/2Uh9NVE

5. World Health Organization. Global Health Observatory Data Repository [Internet]. 2016 [acesso 6 ago 2016]. Disponível: https://bit.ly/2wqg4FH

6. World Health Organization. Public health action for the prevention of suicide: a framework [Internet]. Genebra: WHO; 2012 [acesso 9 jul 2016]. Disponível: https://bit.ly/2y8JYi9

7. World Health Organization. Preventing suicide: a global imperative [Internet]. Genebra: WHO; 2014 [acesso 10 dez 2014]. Disponível: https://bit.ly/2QKem8Y

8. Silva TPS, Sougey EB, Silva J. Estigma social no comportamento suicida: reflexões bioéticas. Rev. bioét. (Impr.) [Internet]. 2015 [acesso 9 jul 2016];23(2):419-26. Disponível: https://bit.ly/3bC2GgH

9. Patel V, Chisholm D, Dua T, Laxminarayan R, Medina-Mora ML, editores. Mental, neurological, and substance use disorders [Internet]. 3a ed. Washington: World Bank; 2015 [acesso 25 mar 2020]. (Disease control priorities, 4). DOI: 10.1596/978-1-4648-0426-7

10. Ballard ED, Cwik M, Storr CL, Goldstein M, Eaton WW, Wilcox HC. Recent medical service utilization and health conditions associated with a history of suicide attempts. Gen Hosp Psychiatry [Internet]. 2014 [acesso 9 jul 2016];36(4):437-41. Disponível: https://bit.ly/2UA6yl2

11. Tait $\mathrm{L}$, Michail M. Educational interventions for general practitioners to identify and manage depression as a suicide risk factor in young people: a systematic review and meta-analysis protocol. Syst Rev [Internet]. 2014 [acesso 11 jul 2016];3(1):145. Disponível: https://bit.ly/3bsZEuK

12. Schaffer A, Sinyor M, Kurdyak P, Vigod S, Sareen J, Reis C et al. Population-based analysis of health care contacts among suicide decedents: identifying opportunities for more targeted suicide prevention strategies. World Psychiatry [Internet]. 2016 [acesso 11 jul 2016];15(2):135-45. Disponível: https://bit.ly/33LEup4

13. Ahmedani BK, Stewart C, Simon GE, Lynch F, Lu CY, Waitzfelder BE et al. Racial/ethnic differences in healthcare visits made prior to suicide attempt across the United States. Med Care [Internet]. 2015 [acesso 9 jul 2016];53(5):430-5. Disponível: https://bit.ly/2vRYOZC

14. Younes N, Chee CC, Turbelin C, Hanslik T, Passerieux C, Melchior M. Particular difficulties faced by GPs with young adults who will attempt suicide: a cross-sectional study. BMC Fam Pract [Internet]. 2013 [acesso 9 jul 2016];14:68. Disponível: https://bit.ly/39kS8Rn 
15. Sendra-Gutiérrez JM, Esteban-Vasallo M, Domínguez-Berjón MF. Características de la conducta suicida y factores asociados a su mortalidad en el ámbito hospitalario. Rev Psiquiatr Salud Ment [Internet]. 2018 [acesso 11 jul 2018];11(4):234-43. Disponível: https://bit.ly/3ajYt0D

16. Gutierrez BAO. Assistência hospitalar na tentativa de suicídio. Psicol USP [Internet]. 2014 [acesso 9 jul 2016];25(3):262-9. Disponível: https://bit.ly/2Ugn0ye

17. Chakravarthy B, Hoonpongsimanont W, Anderson CL, Habicht M, Bruckner T, Lotfipour S. Depression, suicidal ideation, and suicidal attempt presenting to the emergency department: differences between these cohorts. West J Emerg Med [Internet]. 2014 [acesso 9 jul 2016];15(2):211-6. Disponível: https://bit.ly/2QL8g8t

18. Conselho Federal de Medicina. Código de ética médica: Resolução CFM no 1.931/09 [Internet]. Brasília: CFM; 2010 [acesso 18 dez 2014]. Disponível: https://bit.ly/3dxXFYi

19. Beauchamp TL, Childress JF. Principles of biomedical ethics. 5a ed. Nova York: Oxford University Press; 2001.

20. Ho AO. Suicide: rationality and responsibility for life. Can J Psychiatry [Internet]. 2014 [acesso 3 dez 2014];59(3):141-7. Disponível: https://bit.ly/33Lazof

21. Sjöstrand M, Sandman L, Karlsson P, Helgesson G, Eriksson S, Juth N. Ethical deliberations about involuntary treatment: interviews with Swedish psychiatrists. BMC Med Ethics [Internet]. 2015 [acesso 9 jul 2016];16:37. Disponível: https://bit.ly/3dtR5ly

22. Feiring $E$, Ugstad KN. Interpretations of legal criteria for involuntary psychiatric admission: a qualitative analysis. BMC Health Serv Res [Internet]. 2014 [acesso 13 jul 2016];14:500. Disponível: https://bit.ly/2UANTvx

23. Feiring E, Ugstad KN. Op. cit. p. 10.

24. Daolio ER. Suicídio: tema de reflexão bioética. Rev. bioét. (Impr.) [Internet]. 2012 [acesso 11 jul 2016];20(3):436-41. Disponível: https://bit.ly/33NqbAl

25. Graham RD, Rudd MD, Bryan CJ. Primary care providers' views regarding assessing and treating suicidal patients. Suicide Life Threat Behav [Internet]. 2011 [acesso 7 nov 2016];41(6):614-23. Disponível: https://bit.ly/3bwp76V

26. Malakouti SK, Nojomi M, Ahmadkhaniha HR, Hosseini M, Fallah MY, Khoshalani MM. Integration of suicide prevention program into primary health care network: a field clinical trial in Iran. Med J Islam Repub Iran [Internet]. 2015 [acesso 11 jul 2016];29:208. Disponível: https://bit.ly/2wsCl5N

27. Beurs DP, Groot MH, Bosmans JE, Keijser J, Mokkenstorm J, Verwey B et al. Reducing patients' suicide ideation through training mental health teams in the application of the Dutch multidisciplinary practice guideline on assessment and treatment of suicidal behavior: study protocol of a randomized controlled trial. Trials [Internet]. 2013 [acesso 3 dez 2014];14:372. Disponível: https://bit.ly/39kUHTv

28. Associação Brasileira de Psiquiatria, Conselho Federal de Medicina. Suicídio: informando para prevenir [Internet]. Brasília: CFM; 2014 [acesso 6 dez 2014]. Disponível: https://bit.ly/2QKjBFs

29. D'Oliveira CF, Botega NJ, organizadores. Prevenção do suicídio: manual dirigido a profissionais das equipes de saúde mental [Internet]. Brasília: Ministério da Saúde; ca.2006 [acesso 10 dez 2014]. Disponível: https://bit.ly/3eytFMm

30. Bertolote JM, Mello-Santos C, Botega NJ. Detecção do risco de suicídio nos serviços de emergência psiquiátrica. Rev Bras Psiquiatr [Internet]. 2010 [acesso 14 jan 2015];32(supl 2):S87-95. Disponível: https://bit.ly/2UCkzoE

31. Brasil. Ministério da Saúde. Portaria MS no 1.271, de 6 de junho de 2014. Define a Lista Nacional de Notificação Compulsória de doenças, agravos e eventos de saúde pública nos serviços de saúde públicos e privados em todo o território nacional, nos termos do anexo, e dá outras providências. Diário Oficial da União [Internet]. Brasília, 9 jun 2014 [acesso 15 abr 2020]. Disponível: https://bit.ly/34Bx6Nw

32. Conselho Federal de Medicina. Op. cit. p. 34. Tradução livre.

33. Associação Brasileira de Psiquiatria, Conselho Federal de Medicina. Op. cit. p. 13. Tradução livre.

34. Kovács MJ. Op. cit. p. 76. Tradução livre.

\section{Participation of the authors}

Gabriela do Prado Rocha carried out the field research. Gerardo Maria de Araújo Filho conceived the study and oriented the discussion. Lazslo Antônio Ávila participated in the conception and development of the research. All the authors collaborated in writing the text.

\section{Correspondence}

Lazslo Antônio Ávila - Faculdade de Medicina de São José do Rio Preto. Av. Brigadeiro Faria Lima, 5.416 CEP 15090000. São José do Rio Preto/SP, Brasil

Gabriela do Prado Rocha - Undergraduate - gabrielap_rocha@outlook.com

(D) 0000-0002-9791-3564

Gerardo Maria de Araújo Filho - PhD - filho.gerardo@gmail.com

(iD) 0000-0001-7112-8456

Lazslo Antônio Ávila - PhD - lazslo@terra.com.br

(i) 0000-0001-6392-1016 


\section{Appendix}

\section{Research protocol}

Gender: ( ) M ( ) F Age:

Graduation year:

If student: ( ) First year ( ) Sixth year (Skip to numbered statements)

Resident physician: ( ) Yes ( ) No

If resident, what is the year of residence (consider all years of residence):

$($ ) First ( ) Second ( ) Third ( ) Fourth ( ) Fifth ( ) Sixth

Workplace:

( ) Urgency / emergency

( ) ICU

( ) Oncology

( ) Medical clinic ward

( ) General surgery ward

( ) Orthopedics ward

Do you assist patients with suicidal ideation at your workplace? ( ) yes ( ) no

If so, indicate the average weekly attendance of patients with suicidal ideation at your workplace that most closely matches reality:

( ) 1 to 5 patients

( ) 6 to 10 patients

( ) 11 to 15 patients

( ) 16 to 20 patients

( ) More than 21 patients

Do you assist patients with suicide attempts at your workplace?

( ) Yes ( ) No

If so, indicate the average weekly attendance of patients with suicide attempts at your workplace that most closely matches reality:

( ) 1 to 5 patients

( ) 6 to 10 patients

( ) 11 to 15 patients

( ) 16 to 20 patients

( ) More than 21 patients

Check the most appropriate option for the following statements:

1. Suicide is an individual decision, since one has the full right to exercise free will.

( ) I strongly disagree ( ) I disagree ( ) I do not know ( ) I agree ( ) I strongly agree

2. When a person thinks about committing suicide, they will risk suicide for the rest of their life.

( ) I strongly disagree ( ) I disagree ( ) I do not know ( ) I agree ( ) I strongly agree

3. People who threaten to kill themselves will not do so, they just want to get attention.

( ) I strongly disagree ( ) I disagree ( ) I do not know ( ) I agree ( ) I strongly agree

4. If a person felt depressed and was thinking about committing suicide, and in the next moment feels better, it usually means the problem is over.

( ) I strongly disagree ( ) I disagree ( ) I do not know ( ) I agree ( ) I strongly agree 
5. When an individual shows signs of improvement or survives a suicide attempt, they are out of danger.

( ) I strongly disagree ( ) I disagree ( ) I do not know ( ) I agree ( ) Istrongly agree

6. We should not talk about suicide as this can increase the risk.

( ) I strongly disagree ( ) I disagree ( ) I do not know ( ) I agree ( ) I strongly agree

7. Effective treatment of mental illness is the most important pillar of suicide prevention. After the treatment of mental illness, the desire to kill oneself disappears.

( ) I strongly disagree ( ) I disagree ( ) I do not know ( ) I agree ( ) I strongly agree

8. Most suicidal people speak or show signs about their ideas of death.

( ) I strongly disagree ( ) I disagree ( ) I do not know ( ) I agree ( ) I strongly agree

9. Talking to someone about it can ease the anguish and tension that suicidal thoughts bring.

( ) I strongly disagree ( ) I disagree ( ) I do not know ( ) I agree ( ) I strongly agree

10. Patients who are severely depressed, but cognitively intact, may be considered competent to refuse antidepressant medication.

( ) I strongly disagree ( ) I disagree ( ) I do not know ( ) I agree ( ) I strongly agree

11. The breach of medical secrecy in situations involving suicide can be considered ethical and legal.

( ) I strongly disagree ( ) I disagree ( ) I do not know ( ) I agree ( ) Istrongly agree

12. The risk assessment for suicide should be made for all patients, regardless of the presence of explicit suicidal complaints.

( ) I strongly disagree ( ) I disagree ( ) I do not know ( ) I agree ( ) I strongly agree

13. Failure to examine the patient's propensity to commit suicide or to implement an appropriate precautionary plan after the potential for suicide is predicted may lead to professional liability for injury to the individual in a suicide attempt.

( ) I strongly disagree ( ) I disagree ( ) I do not know ( ) I agree ( ) Istrongly agree

14. Every patient who talks about suicide has potential risk and deserves special investigation and attention.

( ) I strongly disagree ( ) I disagree ( ) I do not know ( ) I agree ( ) I strongly agree

15. The verbal approach can be as or more important than medication.

( ) I strongly disagree ( ) I disagree ( ) I do not know ( ) I agree ( ) I strongly agree

16. Although most people at risk of suicide have some mental disorder, most do not seek a mental health professional.

( ) I strongly disagree ( ) I disagree ( ) I do not know ( ) I agree ( ) I strongly agree

17. Electroconvulsive therapy is still the most effective treatment for depression, being reserved primarily for selected cases such as severe depressions, refractory depressions, depressions with psychotic symptoms and depressions with high risk of suicide.

( ) I strongly disagree ( ) I disagree ( ) I do not know ( ) I agree ( ) I strongly agree

18. When identifying a patient at medium risk of committing suicide, the proper conduct would be to request permission to contact family, friends and/or colleagues and explain the situation without alarm or understate, giving only the necessary information and preserving the confidentiality of other information on the particularities of the individual.

( ) I strongly disagree ( ) I disagree ( ) I do not know ( ) I agree ( ) I strongly agree

19. Urgency/emergency: 24-hour surveillance should be structured by someone from the health care team or caregiver, if evaluated as qualified, until medical reassessment. Objects that can be used to injure oneself or others (knives, sharp instruments, medicines, belts and ropes) should be removed from the patient's access, and their belongings should be searched for these items. Doors, including the bathroom, should not be locked.

( ) I strongly disagree ( ) I disagree ( ) I do not know ( ) I agree ( ) I strongly agree 
20. Suicide prevention should start only in centers with a focus on mental health.

( ) I strongly disagree ( ) I disagree ( ) I do not know ( ) I agree ( ) I strongly agree

21. Since June 2014, the National List of Compulsory Notification of diseases, injuries and public health events in public and private health services, throughout the national territory, includes attempted suicide as an immediate compulsory notification within 24 hours from the knowledge of the occurrence.

( ) I strongly disagree ( ) I disagree ( ) I do not know ( ) I agree ( ) I strongly agree

22. According to the Brazilian Code of Medical Ethics, the doctor shall keep confidential information that he knows about in the performance of his duties. Medical confidentiality must be respected even in situations in which the patient has suicidal ideation and is at risk of committing suicide.

( ) I strongly disagree ( ) I disagree ( ) I do not know ( ) I agree ( ) I strongly agree

23. In cases of high risk of suicide, the doctor may hospitalize the patient against their will in order to ensure their life.

( ) I strongly disagree ( ) I disagree ( ) I do not know ( ) I agree ( ) I strongly agree

24. It must be ensured that the person who has just made a suicide attempt is immediately put on treatment to reduce the risk of re-attempting and completing suicide.

( ) I strongly disagree ( ) I disagree ( ) I do not know ( ) I agree ( ) I strongly agree

25. All medical assessments must include:

( ) Mental illness

( ) Personal and family history of suicidal behavior

( ) Suicidality (suicide risk assessment)

( ) Characteristics of personality

( ) Chronic and recent stressors

( ) Psychosocial and demographic factors

( ) Presence of other diseases

26. Were you trained during your graduation to treat patients with suicidal ideation?

( ) I strongly disagree ( ) I disagree ( ) I do not know ( ) I agree ( ) I strongly agree

27. Do you feel prepared to attend patients with suicidal behavior (thoughts, attempts, planning)?

( ) Yes ( ) No

28. On average, what was the total workload (in hours) allocated to this training during your graduation (can include undergraduate classes in one or more subjects, internships focused on the theme and discussions on the topic of suicide)?

29. Did you know or have you heard of the publication Suicide: informing to prevent from the Federal Council of Medicine in partnership with the Brazilian Psychiatric Association?

( ) Yes ( ) No

30. If so, have you read (in whole or in part) the publication Suicide: informing to prevent from the Federal Council of Medicine in partnership with the Brazilian Psychiatric Association?

( ) Yes ( ) No 